\title{
Breeding biology of the pallid harrier Circus macrourus in north-central Kazakhstan: implications for the conservation of a Near Threatened species
}

\author{
J. Terraube, B.E. Arroyo, F. Mougeot, M. Madders, J. Watson and E. A. Bragin
}

\begin{abstract}
We studied a breeding population of pallid harrier Circus macrourus in 2000 and 2006 in northcentral Kazakhstan to evaluate the relationships between breeding parameters and breeding habitat in the species' core breeding range. Pallid harrier nests were found in a wide variety of vegetation types and heights belonging to three main types: steppe, riverine and agricultural. The proportion of nests found in each habitat type (corrected for search effort) differed between 2000 and 2006, with agricultural habitats being more used in 2000, when fallow land was abundant, than in 2006. Highest densities were observed in riverine habitats but hatching success seemed to be lower there because of greater predation. There was apparently lower productivity (smaller broods) in agricultural than in other areas. Laying was spread over 2 months, with a bimodal pattern of laying dates. Birds laid earlier in agricultural and steppe habitats and later in riverine habitats. These differences may be linked to spatio-temporal habitat heterogeneity, and possibly to intra-population heterogeneity in wintering areas implying different arrival dates on the breeding grounds. We discuss the implications of the findings for the conservation of this Near Threatened species.
\end{abstract}

Keywords Agriculture intensification, Circus macrourus, habitat quality, Kazakhstan, pallid harrier, steppe.

\section{Introduction}

$\mathrm{D}$ ata on the breeding biology of viable populations are useful as a reference to evaluate causes of decline and develop appropriate actions in other populations of con-

J. Terraube* (Corresponding author), B.E. Arroyo and F. Mougeot ${ }^{\dagger}$ IREC (CSIC-UCLM-JCCM), Ronda de Toledo s/n, 13005, Ciudad Real, Spain. E-mail julien.terraube@uclm.es

M. MAdDers Natural Research Ltd, Banchory Business Centre, Burn O’Bennie Road, Banchory, AB31 5ZU, UK.

J. WATson Scottish Natural Heritage, 9 Culduthel Road, Inverness, IV2 4AG, UK.

E.A. Bragin Science Department, Naurzum National Nature Reserve, Kustanay Oblast, Naurzumski Raijon, Karamendi 459730, Kazakhstan.

*Also at: Natural Research Ltd, Banchory Business Centre, Burn O’Bennie Road, Banchory, AB31 5ZU, UK.

${ }^{\dagger}$ Also at: University of Aberdeen, King's College, Aberdeen, AB24 3FX, UK.

Received 14 April 2007. Revision requested 26 June 2007.

Accepted 12 October 2007. servation concern. For example, information on selection of breeding habitat or the relationship between habitat and breeding success can provide insights into how much habitat changes may influence breeding populations. The pallid harrier Circus macrourus is a migratory raptor that breeds from the Volga River eastwards through the Urals, southern Siberia, northern Kazakhstan and north-western China (del Hoyo et al., 1994). Its main population strongholds are in southern Asian Russia and northern Kazakhstan, which hold c. $87 \%$ of the world population. The species has been declining in recent decades and its range distribution has been fragmented, especially at its western limits (Davygora \& Belik, 1994). Population trends in Asia have been less well documented, although local declines have been reported (Davygora \& Belik, 1994). The pallid harrier is categorized as Near Threatened on the IUCN Red List (Collar et al., 1994; IUCN, 2007).

Declines have been attributed to habitat degradation and agricultural intensification leading to breeding habitat deterioration, reductions in prey availability, and contamination by toxic pesticides on breeding and wintering areas (Davygora \& Belik, 1994; BirdLife International, 2003). However, the few studies of this species have mainly dealt with numbers and distribution (Bragin, 2003; SanchezZapata et al., 2003; Morozov \& Bragin, 2005). Thus, relatively little is known about the general ecology and requirements of the pallid harrier, and there is no up-to-date information on its breeding biology. In southern Kazakhstan the species is more common in natural saline steppe than in modified habitats (Sanchez-Zapata et al., 2003). It may also have benefited from forest clearance and adapted to agricultural habitat but it is considered to be essentially a breeder on natural grasslands (del Hoyo et al., 1994; Snow \& Perrins, 1998). Overall, the relationships between the species' breeding and habitat are little known, and we know of no attempt to quantify whether breeding parameters change in relation to breeding habitat.

In this paper we report on a 2-year study, conducted in north-central Kazakhstan, on a breeding population of pallid harriers situated in the core of the species' breeding range. Our aim was to provide basic information on the breeding biology of the species, with particular emphasis on variations in nesting habitat selection and breeding parameters (density, phenology and success) in relation to habitat. We conclude by discussing the implications of our results for the conservation of the species. 


\section{Study area}

The study was conducted in June 2000 and June 2006 in the Naurzum National Nature Reserve (Kostanay Oblast, north-central Kazakhstan; Fig. 1). This area (the southern limit of Siberian forest and northern limit of Eurasian steppe) is characterized by a mosaic of dry steppes with feather grass Stipa spp. and bunch grasses on the poorer soils, and low sagebrush Artemisia spp. and other nutrient rich shrubs and grasses on denser soils (used mainly for extensive sheep, horse and cattle grazing). Interspersed within the steppe matrix are woodland patches dominated by Scots pine Pinus sylvestris, birch Betula spp. and aspen Populus spp. There are also numerous permanent and ephemeral lakes holding saline or fresh water, and rivers edged by reeds. More than $50 \%$ of the steppe in the study area was ploughed for wheat cultivation during the 'virgin lands' programme initiated in the 1950 s to open up a vast tract of steppe land, mainly in northern Kazakhstan, for grain cultivation. Much of this area turned to fallow following the dissolution of the USSR in the 1990s (Katzner et al., 2003), although we observed a trend for agricultural re-intensification over 2000-2006.

\section{Methods}

\section{Data collection}

We located nests by following males carrying prey and locating where females landed after a food pass. During the first survey (June 2000), 24 pallid harrier nests (of 35 located) were visited. An additional five pallid harrier broods were found after fledging. In June 2006 we found and visited 45 pallid harrier nests; $66 \%$ of the visited nests were visited twice and $34 \%$ only once. Upon our first visit we recorded vegetation type, density and height in the vicinity of the nest. During each visit, we also recorded clutch size, number of young, and measured wing length of nestlings. The location of nests and known pairs was determined using a global positioning system (GPS). In 2006, first year females were identified according to plumage (Forsman, 1999).

\section{Estimation of breeding parameters}

Laying date was estimated directly if the nest was visited during laying, or by subtracting 30 days from the estimated date of hatching. Nestlings were aged using wing-length growth curves for a similar sized species (hen harrier Circus cyaneus; Brignon, 1997). Estimated laying date is thus expected to have an associated error but we considered it unlikely to be more than a few days or to affect the general findings. We also categorized each nest as 'early' (if laying date was earlier than the observed average for each year) or 'late' (later than annual average).

Fieldwork was undertaken during a short time, covering only part of the breeding season. The evaluation of breeding parameters is thus necessarily restricted and subject to some biases. For example, final clutch size was known for

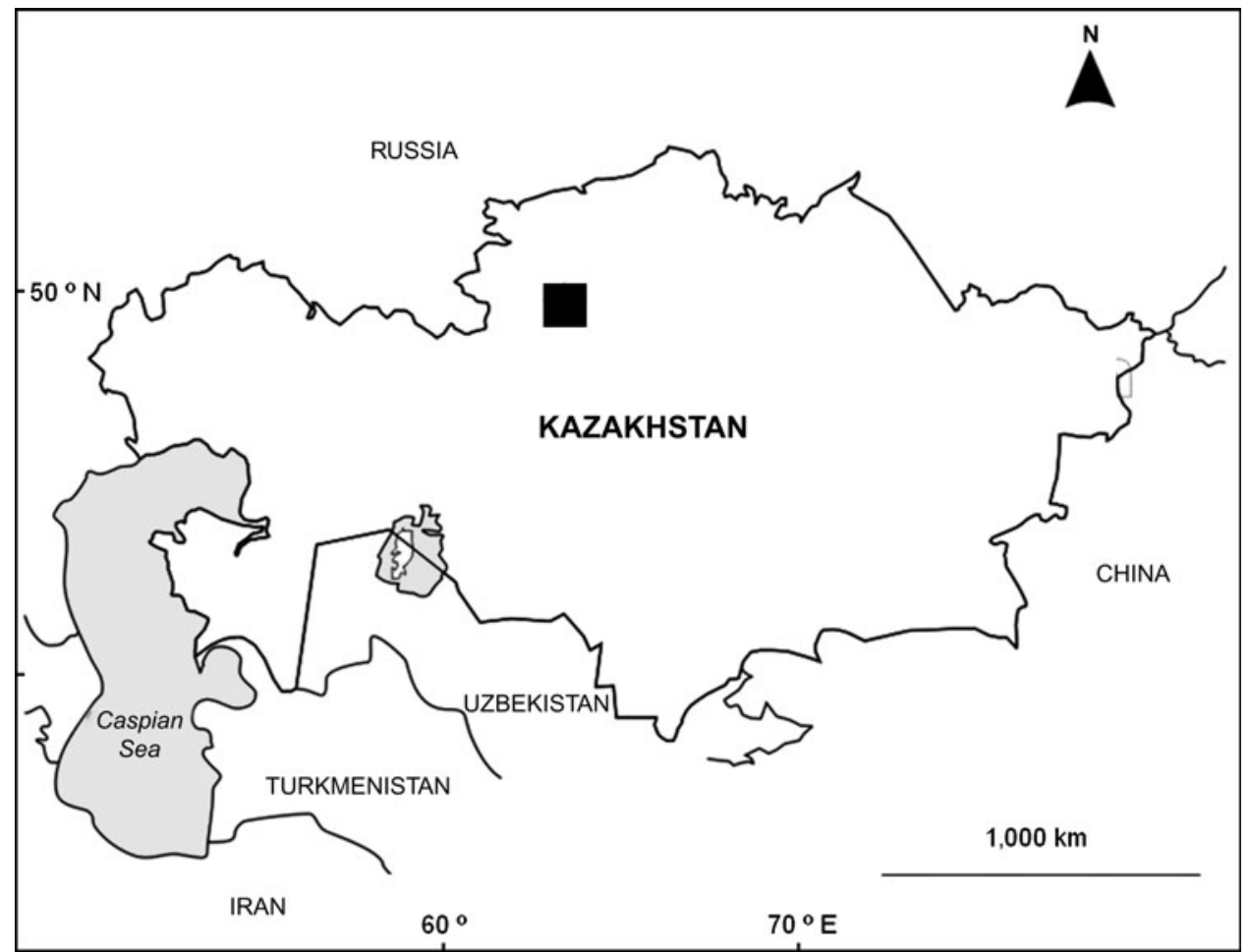

Fig. 1 Location of the study area (represented by the black rectangle) in the Naurzum area in north-central Kazakhstan. 
late breeders (which were still incubating eggs at the time of the first nest visit), but not for early breeders. To make sure that observed trends were not exclusively arising from these biases, we used two different sets of variables in analyses: known clutch size (using only those nests for which the final clutch size was known), and approximate clutch size (including a minimum clutch size, equal to brood size at the time of first visit) for those nests already hatched at the time of our first visit but where nestlings were not older than 2 weeks; if nestlings were older, we did not take this nest into account for the estimation of clutch size.

Hatching success was estimated by modulating the observed failure rate by the exposure time (number of days between first and second visit; Mayfield, 1975). Nests visited only once were not included in this analysis. There was not enough information to evaluate fledging success or nestling mortality, as insufficient nests were visited more than once after hatching. We simply present data on the brood sizes observed.

Between-nest distances were calculated using the geographical information system Arc View v. 3.2 (ESRI, Redlands, USA) from GPS locations. We used data from all nests located, including those visited $(\mathrm{n}=74)$ and others of known location but not visited $(\mathrm{n}=11)$. We also calculated for each nest the number of breeding neighbours within $1 \mathrm{~km}$.

\section{Statistical analysis}

Analysis of habitat shifts between years was carried out with a generalized linear model, with number of nests as the response variable (fitted to the model with a Poisson distribution), and habitat type, year and their interaction as the explanatory variables. To eliminate biases associated with search effort, we included the log of the number of days spent prospecting in each habitat type as an offset in the model. Comparisons between groups were tested with least square means (LSM) differences.

To test for differences in laying date and breeding density between habitat types, laying date or distance to the nearest neighbour were fitted using a normal distribution. Number of neighbours within a 1-km radius was fitted with a Poisson distribution. Explanatory variables included habitat, year and their interaction.

To investigate the relationship between clutch size, habitat and breeding phenology, clutch size was fitted to models using a normal distribution. The initial model contained habitat, laying date, year and their interactions. Non-significant terms were removed sequentially until the most parsimonious model was obtained. We considered only two habitat types (riverine and steppe) because there were too few clutch size data for agricultural areas to allow modelling.

\section{Results}

\section{Breeding habitat}

Pallid harrier nests were found in a wide variety of contexts (Table 1). Nest vegetation type ranged from sparse steppe dominated by Artemisia or graminous plants to dense reeds or dwarf scrub (forest-steppe transition zone). Vegetation height at the nest site averaged $106 \pm S D 72 \mathrm{~cm}(\mathrm{n}=66)$, but was also highly variable (extremes o and $280 \mathrm{~cm}$, from nests placed in a ploughed field and a deep reed bed, respectively). Although most nests were on dry ground, $23 \%$ were built above water (mean water depth at the time of visit: $36 \pm$ SD $21 \mathrm{~cm}$; range 10-100, $\mathrm{n}=17$ ).

Nesting habitats could be grouped into three main types: riverine-like habitats (reeds within river channels, lake edges or shallow water areas), steppe habitats (dominated by graminous plants and Artemisia), and agricultural areas (a mixture of abandoned and cultivated wheat fields). The proportion of nests found in each habitat type (corrected for search effort) differed between 2000 and 2006 (Table 2). This shift in habitat use was statistically significant (habitat: $\chi_{2}^{2}=7.61, \mathrm{P}=0.02$; year: $\chi_{1}^{2}=0.23, \mathrm{P}=0.63$; year $\times$ habitat: $\left.\chi_{2}^{2}=11.50, \mathrm{P}=0.003\right)$. Nests were found more frequently in agricultural habitats in 2000 than in 2006 (Table 2, differences in LSM $\left.\chi_{1}^{2}=4.92, \mathrm{P}=0.02\right)$, and marginally more frequently in steppe areas in 2006 than in 2000 (differences in LSM $\chi_{1}^{2}=3.65, \mathrm{P}=0.056$ ). No between-year difference was found in the use of riverine habitats (differences in LSM $\chi_{1}^{2}=1.05, \mathrm{P}=0.30$ ).

Distance to nearest breeding neighbour averaged 1,260 \pm SD $1,350 \mathrm{~m}$ (range $55-9,500 \mathrm{~m}, \mathrm{n}=83$ active nest sites). Average breeding density (number of breeding neighbours present within a $1 \mathrm{~km}$ circle around each nest) was $2.01 \pm$ SD 2.10. It differed between years (being higher in 2006; Table 2), and between habitats after controlling for year (year: $\chi^{2}=7.15, \mathrm{P}=0.0075$; habitat: $\chi^{2}=10.29, \mathrm{P}=0.0058$ ).

TABLE 1 Numbers of pallid harrier nests found in the Naurzum area, north-central Kazakhstan (Fig. 1), in 2000 and 2006, in the various vegetation types.

\begin{tabular}{lcc}
\hline & \multicolumn{2}{c}{ Number of nests } \\
\cline { 2 - 3 } Vegetation type & 2000 & 2006 \\
\hline Artemisia & 1 & 6 \\
Artemisia \& steppe grass & 0 & 1 \\
Artemisia \& ray grass & 3 & 0 \\
Ray grass & 1 & 2 \\
Steppe grass & 0 & 11 \\
Phragmites & 10 & 23 \\
Phragmites \& Typha & 3 & 0 \\
Wheat fields (bare ground at laying) & 3 & 0 \\
Set-aside/wheat & 3 & 0 \\
Set-aside & 5 & 2 \\
Total & 29 & 45 \\
\hline
\end{tabular}


TABLE 2 Summary of breeding parameters for pallid harriers in the Naurzum area, north-central Kazakhstan (Fig. 1), in 2000 and 2006.

\begin{tabular}{lll}
\hline Breeding parameter & 2000 & 2006 \\
\hline Mayfield nest hatching success & 0.61 \\
Mean known clutch size $( \pm$ SD) & 0.63 & $5.74 \pm 1.12$ \\
Mean estimated clutch size $( \pm$ SD) & $5.9 \pm 0.57$ & $5.45 \pm 1.21$ \\
Number of failed nests & $5.17 \pm 1.20$ & 6 \\
Mean minimal brood size $( \pm$ SD) & 1 & $4.54 \pm 1.44$ \\
Proportion 1st year breeding females & $4.20 \pm 1.47$ & $35 \%(\mathrm{n}=44)$ \\
Proportion nesting & $?$ & $5.5 \%(\mathrm{n}=44)$ \\
Agricultural land & $27.5 \%(\mathrm{n}=40)$ & $52.3 \%$ \\
Riverine areas & $60.0 \%$ & $43.2 \%$ \\
Steppe & $12.5 \%$ & $0(\mathrm{n}=2)$ \\
Mean no. of neighbours $( \pm$ SD) & & $2.92 \pm 2.22(\mathrm{n}=24)$ \\
Agricultural land & $0.88 \pm 1.27(\mathrm{n}=9)$ & $2.22 \pm 2.88(\mathrm{n}=18)$ \\
Riverine areas & $1.09 \pm 0.66(\mathrm{n}=25)$ & 2 \\
Steppe & $3.60 \pm 0.55(\mathrm{n}=5)$ & 7 \\
No. of prospecting days & & 8 \\
Agricultural land & 2 & \\
Riverine areas & 9 & \\
Steppe & 5.5 & \\
\hline
\end{tabular}

${ }^{*}$ Calculated using Mayfield (1975)

Breeding densities were lower in agricultural zones than in riverine (LSM $\left.\chi_{1}^{2}=6.30, \mathrm{P}=0.0121\right)$ or steppe habitats $\left(\mathrm{LSM} \chi_{1}^{2}=8.11, \mathrm{P}=0.0044\right)$.

\section{Breeding phenology and relationship to habitat}

Laying onset extended over $>2$ months in both study years (Fig. 2). The distribution of laying dates appeared to be bimodal, with a first peak in mid April and a second peak at the end of May and early June (Fig. 2). Laying dates differed significantly between habitats (Fig. 3; habitat: $\chi_{2}^{2}=7.78$, $\mathrm{P}=0.02$; year: $\chi_{1}^{2}=0.01, \mathrm{P}=0.99$; year $\times$ habitat: $\chi_{2}^{2}=2.53$, $\mathrm{P}=0.28)$. Pairs breeding in agricultural habitats laid earlier than those breeding in steppe (LSM $\chi_{1}^{2}=5.85, \mathrm{P}=0.01$ ) or riverine habitats $\left(\mathrm{LSM} \chi_{1}^{2}=7.97, \mathrm{P}=0.004\right)$.

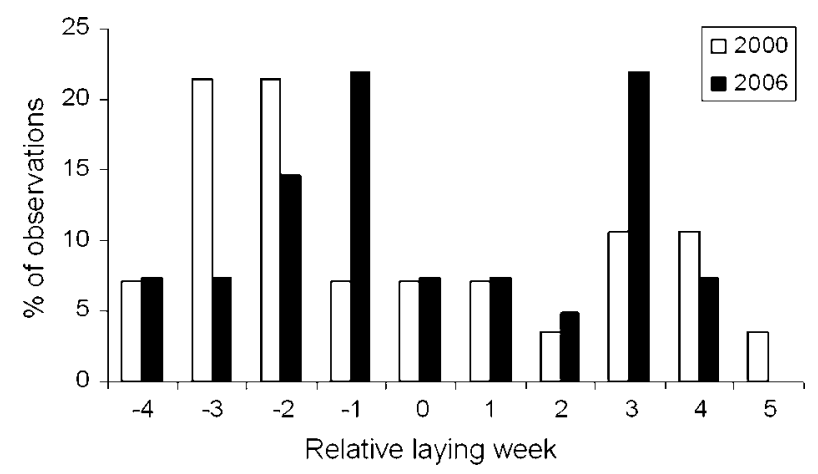

FIG. 2 Frequency distribution of relative laying week (where 0 represents the average laying date for each study year) of pallid harriers in 2000 and 2006.
Breeding parameters and relationships to habitat and phenology

Clutch size averaged 5.72 \pm SD $1.00(n=33)$, and varied with laying date (Fig. 4c). When analysing known clutch sizes (i.e. only those nests known to have completed clutches), it decreased linearly with lay date, with an almost significant effect of habitat (lay date: $\chi_{1}^{2}=6.56, \mathrm{P}=0.01$; habitat: $\chi_{1}^{2}=3.82, \mathrm{P}=0.051$; interaction: $\left.\chi_{2}^{2}=3.37, \mathrm{P}=0.066\right)$. In this model the estimated clutch size for early birds would be $>8$; Fig. 4a). When analysing approximate clutch size (i.e. including those nests with estimated minimum clutch size), clutch size variation was only explained by laying date (quadratic relationship; lay date: $\chi_{1}^{2}=5.85, \mathrm{P}=0.015$; lay date $^{2}: \chi_{1}^{2}=5.59, \mathrm{P}=$ 0.018; Fig. 4b).

Of all nests visited with eggs $(n=37)$ five were found to have failed, all in 2006. The average Mayfield (1975) estimator of nest hatching success was $61.1 \%$ (confidence

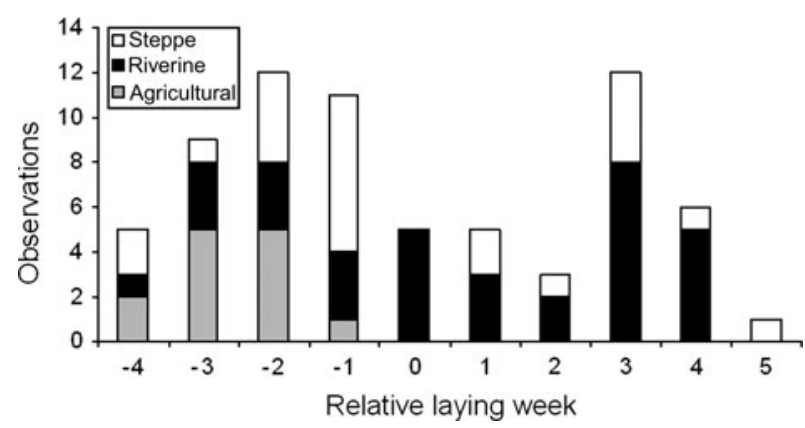

FIG. 3 Frequency distribution of relative laying dates (both study years combined, where 0 represents the average laying date) in the three breeding habitats (see text for further details). 

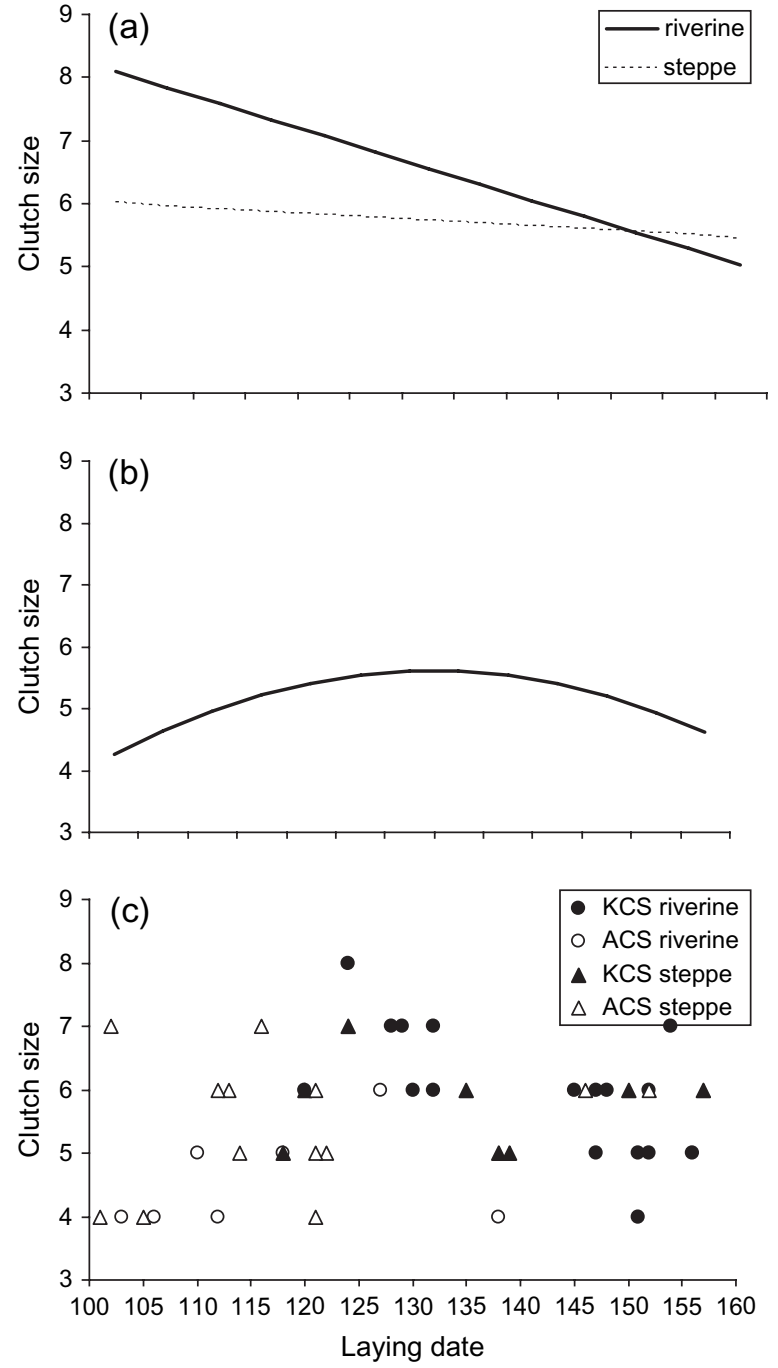

FIG. 4 Relationship between clutch size of the pallid harrier (2000 and 2006 data combined) and laying date (expressed in Julian dates, where $1=1$ January and $32=1$ February, etc.).

(a) Output of the most parsimonious model explaining known clutch size for riverine and steppe habitats, which included laying date and habitat as explanatory variables; (b) output of the most parsimonious model explaining approximate clutch size, which included only laying date as an explanatory variable; (c) the raw data (KCS, data from nests with known clutch size; ACS, data from nests with approximate clutch size) for riverine and steppe habitats. Output is presented for the range of observed laying dates (i.e. 10 April-15 June).

limits $42.3-79.8 \%$, assuming a 30 -day incubation period). Average egg survival rate was highest in steppe habitat (77.6\%) and lowest in riverine habitat (52.3\%). Average egg survival rates were similar for early $(82.2 \%)$ and late $(88.4 \%)$ nests. Predation appeared to be the main cause of nest failure during incubation $(13.1 \%$ of all nests; $80 \%$ of failed nests). Predation occurred mainly in reed-beds (four of the five nests lost).

Mean brood size at the time of the last visit was $3.93 \pm$ SD $1.75(n=44)$. Mean observed brood size in steppe habitats
( $4.87 \pm \mathrm{SD} 1.42, \mathrm{n}=16)$ was slightly higher than in riverine habitats $(4.00 \pm S D 1.60, n=15)$ but differences were not significant $\left(\mathrm{LSM} \chi^{2}=1.55 ; \mathrm{P}=0.21\right.$ ). The observed brood size in agricultural habitats $(2.69 \pm \mathrm{SD} 1.93, \mathrm{n}=13)$ was significantly lower than in steppe habitats (LSM $\chi^{2}=13.01$, $\mathrm{P}=0.003)$ and riverine habitats $\left(\mathrm{LSM} \chi^{2}=5.64, \mathrm{P}=0.018\right)$.

In the year when females were aged $(2006), 35 \%(n=20)$ of the breeding females observed were yearlings. First-year females bred in both steppe $(44 \%, \mathrm{n}=9)$ and riverine habitats $(30 \%, \mathrm{n}=10)$, in similar proportions (Fisher exact test, $\mathrm{P}=0.43$ ). They were not significantly more frequent amongst early $(27 \%, \mathrm{n}=11)$ than late breeders $(44 \%, \mathrm{n}=9$; Fisher exact test, $\mathrm{P}=0.370$ ).

\section{Discussion}

A striking result of our study was the diversity of breeding habitats used by pallid harriers in terms of vegetation cover, structure and proximity to water. Breeding was not dependent on the presence of steppe vegetation, and pallid harriers were found to breed in agricultural areas, at least when agriculture is non-intensive (as in 2000). Breeding densities were highest in rivers and riverine habitats, where clutch sizes appeared larger for early breeders but where hatching success seemed to be lowest (principally because of greater predation). Agricultural areas seemed to be associated with smaller broods. However, these results have to be considered cautiously because most nests in this habitat were found late in the breeding cycle, so some nestlings may have dispersed and not been detected. We also found phenological differences linked to breeding habitats: early breeders mainly settled in steppe and agricultural habitats, whereas late breeders mostly occupied riverine habitats.

These results have contradictory interpretations in relation to the heterogeneity of habitat quality in the study area. Differences in habitat structure could create spatial variation in rodent and passerine availability and ultimately in the quality of the foraging resource for breeding harriers. Rodent abundance generally increases with tall vegetation cover (Jacob, 2003) and vegetation structure heterogeneity (Evans et al., 2006). Higher rodent densities may thus be expected along riverine habitats than in steppe habitats, which could explain the high breeding densities encountered in these areas and the large estimated clutch size for early breeders there. However, individuals of higher phenotypic quality are commonly observed to arrive and mate first, and to occupy the most productive territories (Currie et al., 2000; Gunnarsson et al., 2005; Kokko, 2006; Sergio et al., 2007). If areas along riverine habitats are better foraging areas it would be more advantageous for the birds arriving earlier to nest early in these habitats. Contrary to this expectation, we found that the earliest breeders nested in steppe or agricultural areas. One potential explanation could 
be that habitat selection varies in response to temporal changes in habitat quality, e.g. because of variation in snow cover. For instance, snow accumulates more in ditches and rivers than open areas such as steppes and agricultural fields during the winter season (e.g. Huitu et al., 2003). In spring, ditches are likely to retain snow longer than the surrounding steppe, and melting snow is likely to cause high water levels in rivers and lakes, delaying vegetation growth. Thus steppe areas may act as refuges for rodents at this time, attracting foraging harriers. Later, when water levels decline, the riverbank vegetation growth would encourage harriers to hunt closer to the riverbed. Hence, by influencing vegetation growth, variations in snow cover and water level could determine the timing of optimum conditions for breeding in riverine habitats.

In addition, high quality habitats can exhibit different characteristics in different years (Hakkarainen et al., 2003; Lohmus, 2003). It is important to note that both study years were probably good in terms of prey abundance. This was evidenced by frequent observations of voles (Authors, pers. obs.) and pallid harrier numbers comparable to those of peak vole-years (Bragin, 2003). Thus, habitat quality for breeding pallid harriers in the Naurzum area may vary in both time and space, depending on prey composition, abundance and distribution. We observed frequent and early use of agricultural habitats in one of the years of the study (although with apparently small brood sizes) but it may be that agricultural habitats are not adequate in all years. Another hypothesis is that a shift is currently occurring, with agricultural habitat becoming less suitable as breeding areas because of agriculture intensification (Sergio et al., 2003). It seems that in our study area, in connection with favourable weather conditions over the last 4 years, areas used for intensive cereal cultivation have increased locally (Bragin, 2003) leading to a decline in the extent of fallow land.

Laying onset in both years was more extended than in other harriers (hen harrier Circus cyaneus and Montagu's harrier Circus pygargus) breeding in Western Europe, or in the sympatric C. pygargus (same study area; Table 3, Fig. 5). Laying was spread over 2 months, with two distinct peaks. This frequency distribution of laying dates was significantly different from that of other species (Kolmogorov Smirnov tests between $C$. cyaneus and C. pygargus: $\mathrm{P}=0.14$; between C. cyaneus and C. macrourus: $\mathrm{P}=0.05$ and between C. pygargus and C. macrourus: $\mathrm{P}=0.003$; Fig. 5 ).

The second peak of laying could have been because of relays of failed nests. This was unlikely, however, because it was too marked and was observed in both years, and these years appeared to be good years in terms of food abundance (and therefore breeding success). Moreover, the second peak was not associated with lower reproductive performance, as commonly found with relays (Hipfner et al., 1999). Another possibility is that there was a large variation in individual quality among the breeders, with some birds taking much longer to attain breeding condition. Birds that lay late in the season tend to be younger, less experienced, and/or of lower quality than those that lay early (Parsons, 1975; Newton, 1979; Arnold et al., 2004). If that was the case, one would expect to observe a much stronger difference in breeding parameters (such as clutch size or breeding success) between the early and late breeders. A limitation of our study is that we do not have comparable data for early and late breeders, and in particular we had few known clutch size data for early breeders, so our models may be biased. Nevertheless, the available data suggest that early nesters did not necessarily lay bigger clutches or breed more successfully than late ones. Furthermore, in 2006 a similar proportion of first-year females bred early or late.

Another, and in our opinion more likely, explanation is that individuals of different wintering origin coexist within the study site and breed sympatrically (Møller \& Hobson, 2003). Pallid harriers from different wintering grounds (e.g. India vs Africa) may arrive on the breeding grounds, and therefore lay, at different times. This could also explain the apparent lack of relationship between clutch size and laying date (as one of our models suggests) because the relationship between these variables would be highly complex

TABLE 3 Degree of laying synchrony, defined as the percentage of all breeding birds that, within a breeding season, start breeding within a period of 3 or 4 consecutive weeks, in the various populations of Montagu's, hen and pallid harriers.

\begin{tabular}{llrrl}
\hline Species & Location & 3 weeks & 4 weeks & Reference \\
\hline Montagu's harrier Circus pygargus & N Kazakhstan & 89 & 89 & Authors (unpubl. data) \\
& E France & $>75$ & $>90$ & Millon et al. (2002) \\
& W France & 74 & 86 & V. Bretagnolle \& B. Arroyo (unpubl. data) \\
& Central Spain (Madrid) & 74 & 87 & B. Arroyo \& J. García (unpubl. data) \\
& Central Spain (CLM) & $>75$ & $>85$ & Castaño (1995) \\
Hen harrier Circus cyaneus & E France & $>70$ & $>80$ & Millon et al. (2002) \\
& W France & 78 & 86 & V. Bretagnolle \& B. Arroyo (unpubl. data) \\
& Central Spain & 59 & 74 & B. Arroyo \& J. García (unpubl. data) \\
Pallid harrier Circus macrourus & UK & $>70$ & $>80$ & Etheridge et al. (1997) \\
\hline
\end{tabular}



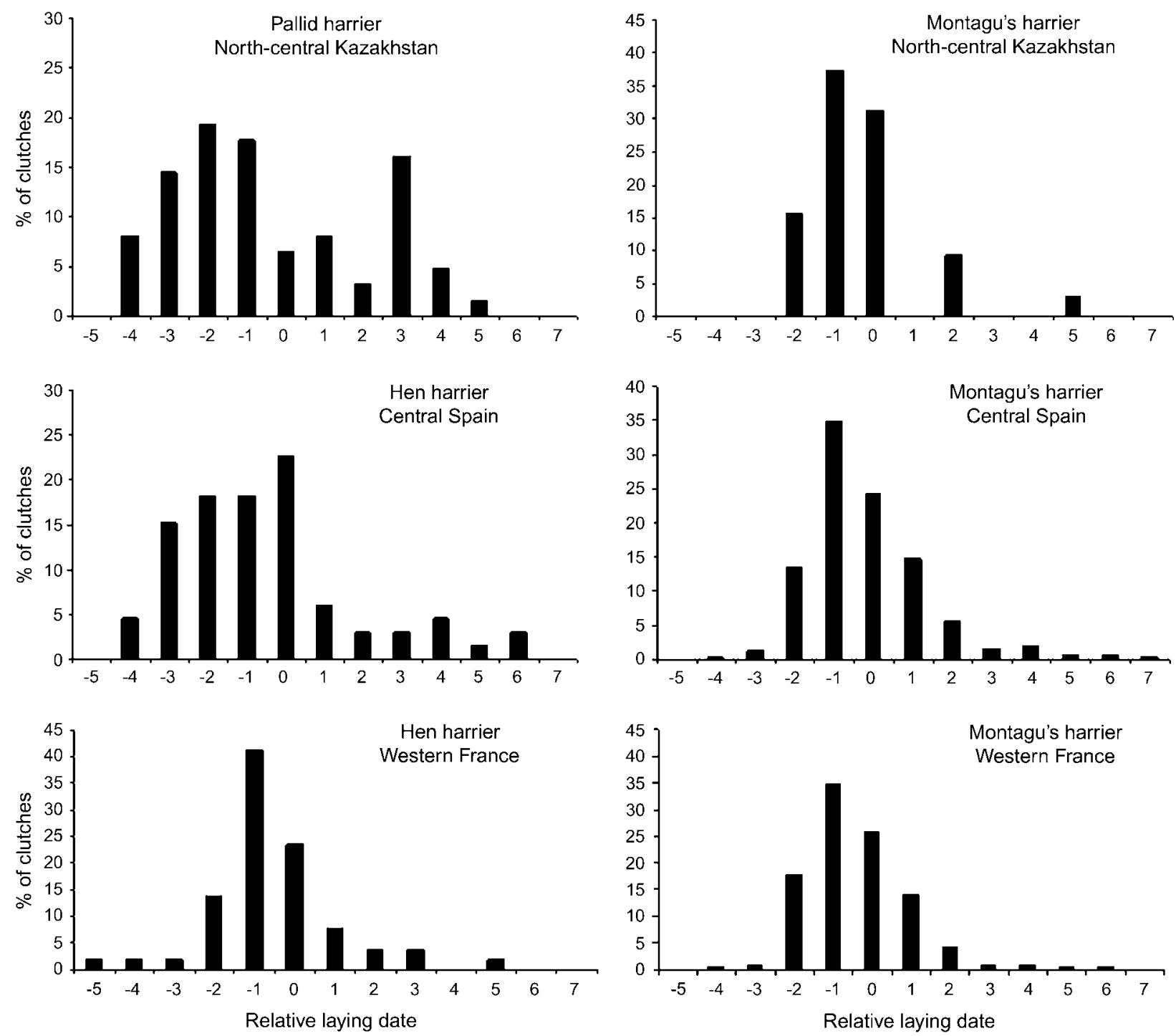

FIG. 5 Frequency distribution (note the differing vertical scales) of relative laying dates in pallid, hen and Montagu's harriers in northcentral Kazakhstan (this study), central Spain (B. Arroyo \& J. García, unpubl. data) and western France (B. Arroyo \& V. Bretagnolle, unpubl. data).

(for a given date there may be breeding individuals of different origins and different qualities). In any case, birds arriving early (potentially from one wintering area) may nest preferentially in one type of habitat, i.e. the one of highest quality at the time, whereas birds arriving later may nest preferentially in another type, the relative quality of available habitats having changed.

Our results indicate that pallid harriers can breed in agricultural habitats, at least in years when food and fallow land are abundant, but that this use may be associated with lower brood sizes. However, the lack of nests in agricultural areas in 2006 (when agriculture had intensified) imply that further research is needed to evaluate the relationship between agricultural practices and their impacts on habitat, food abundance, breeding density and, ultimately, productivity. Kazakh steppe ecosystems have been modified by extensive nomadic pastoralism over many years. These habitats may undergo further modification as a result of changes in grazing regimes. Cattle stocks appear to have increased in recent years (Bragin, 2003) and increased grazing pressure could reduce habitat heterogeneity and prey abundance, leading to declines in the hunting success of harriers (Amar \& Redpath, 2005). In combination with changes in grazing pressure, the integration of Kazakhstan into intensive agricultural markets (through increased cereal production at the expense of non-intensive pastoralism) in recent years has seen an increase in the extent of agricultural habitats and a decrease of fallow land. We may suppose that future progression of crops over steppe areas or fallow will accentuate this trend, leading to highly unpredictable breeding performance in pallid harriers. 
Conservation management for pallid harriers in their breeding areas should be directed towards the development of measures directed to maintaining food supplies (e.g. through the maintenance of extensive pastoralism practices, or the maintenance of fallow areas within farmed land) as well as others to minimize any decrease in favourable breeding habitats. This could be implemented by measures directed to the conservation of riverine habitats and small wetlands within steppe areas, which seem to be actively selected as breeding habitats even in low-vole years (Authors, pers. obs).

Additionally, if the Naurzum pallid harrier population is structured in two subpopulations with different wintering areas, this would have implications for the dynamics of both sub-populations if winter conditions differ. Migratory bird populations may be limited primarily by events related to mortality or habitat availability on the tropical wintering grounds (Marra \& Holberton, 1998; Newton, 2004; Norris et al., 2004). As different wintering areas may be subject to different pressures, this could result in intra-population heterogeneity in survival, and impact on long-term population dynamics. We believe it is essential to assess whether winter habitat locations and quality influence arrival dates on the breeding grounds and breeding success (see Gunnarsson et al., 2005, for a similar case).

To our knowledge no conservation measures have yet been planned for this species on its breeding grounds but our continuing collaboration with local conservation organizations, together with the information from ongoing research, will allow a conservation plan to be developed. Ongoing research on this species includes the use of satellite transmitters to evaluate wintering areas (Natural Research, 2008b), and ecological studies of habitat needs in winter areas (Natural Research, 2008a).

\section{Acknowledgements}

We thank Becky Wills, Ainur Akhmetova, Robert Stakim, Alexey Timoshenko, Maxim Glushkov and Slava for help with data collection and logistics. We thank Zhanbosynov Mirzabek Sukmenovich, director of the Naurzum National Reserve, and the deputy director Zeinelova Maria Alexandrova, for giving us the opportunity to work on the Reserve. We also thank Todd Katzner for assistance in setting up the project, logistics, and comments on the manuscript. Thanks also to G. Bortolotti, F. Sergio and an anonymous referee for helpful comments on the manuscript.

\section{References}

Amar, A. \& Redpath, S. (2005) Habitat use by hen harrier Circus cyaneus on Orkney: implications of land-use change for this declining population. Ibis, 147, 37-47.
Arnold, J.M., Hatch, J.J. \& Nisbet, I.C.T. (2004) Seasonal declines in reproductive success of the common tern Sterna hirundo: timing or parental quality? Journal of Avian Biology, 35, 33-45.

Birdife International (2003) International Action Plan for the Pallid Harrier (Circus macrourus). Convention on the Conservation of European Wildlife and Natural Habitats, Standing Committee. 23rd Meeting, Strasbourg, 1-4 December 2003.

Bragin, E.A. (2003) Distribution, number and some features of ecology of the pallid harrier (Circus macrourus) in Kustanai region. Selevinia, 2003, 145-149. [in Russian]

Brignon, A.L. (1997) Croissance et métabolisme chez des poussins de Busard cendré (Circus pygargus) élevés en captivité. Thèse de doctorat vétérinaire, Ecole Nationale Vétérinaire de Nantes, Nantes, France.

CASTAÑo, J.P. (1995) Ecología reproductiva del aguilucho cenizo Circus pygargus en el Campo de Montiel. $\mathrm{PhD}$ thesis, Universidad Complutense, Madrid, Spain.

Collar, N.J., Crosby, M.J. \& Stattersfield, A.J. (1994) Birds to Watch 2. The World List of Threatened Birds. BirdLife International, Cambridge, UK.

Currie, D., Thompson, B.A. \& Burke, T. (2000) Patterns of territory settlement and consequences for breeding success in the northern wheatear Oenanthe oenanthe. Ibis, 142, 389-398.

Davygora, A.V. \& Belik, V.P. (1994) The pallid harrier Circus macrourus as an endangered species in the Palearctic. In Raptor Conservation Today: Proceedings of the IV World Conference on Birds of Prey and Owls (eds B.-U. Meyburg \& R.D. Chancellor), pp. 93-96. WWGBP/The Pica Press, Bodmin, UK.

Del Hoyo, J., Elliott, A. \& Sargatal, J. (1994) Handbook of the Birds of the World: Vol. 2. New World Vultures to Guineafowl. Lynx Edicions, Barcelona, Spain.

Etheridge, B., Summers, R.W. \& Green, R.E. (1997) The effects of illegal killing and destruction of nests by humans on the population dynamics of the hen harrier Circus cyaneus in Scotland. Journal of Applied Ecology, 34, 1081-1105.

Evans, E.D., Redpath, S.M., Elston, D.A., Evans, S.A., Mitchell, R.J. \& Dennis, P. (2006) To graze or not to graze? Sheep, voles, forestry and nature conservation in the British uplands. Journal of Applied Ecology, 43, 499-505.

Forsman, D. (1999) The Raptors of Europe and the Middle East. A Handbook of Field Identification, 2nd edition. A \& C Black Publishers Ltd, London, UK.

Gunnarsson, T.G., Gill, J.A., Newton, J., Potts, P.M. \& Sutherland, W.J. (2005) Seasonal matching of habitat quality and fitness in a migratory bird. Proceedings of the Royal Society, B, $272,2319-2323$.

Hakkarainen, H., Mykrä, S., Kurki, S., Korpimäki, E., Nikula, A. \& Koivunen, V. (2003) Habitat composition as a determinant of reproductive success of Tengmalm's owl under fluctuating food fluctuations. Oikos, 100, 162-171.

Hipfner, J.M., Gaston, A.J., Martins, D.L. \& Jones, I.L. (1999) Seasonal declines in replacement egg-layings in a long-lived, Artic seabird: costs of late breeding or variation in female quality? Journal of Animal Ecology, 68, 988-998.

Huitu, O., Norrdahl, K. \& Korpimäki, E. (2003) Landscape effects on temporal and spatial properties of vole population fluctuations. Oecologia, 135, 209-220.

IUCN (2007) 2007 IUCN Red List of Threatened Species. IUCN, Gland, Switzerland. Http://www.redlist.org [accessed 4 June 2008].

ЈАСОВ, J. (2003) Short-term effects of farming practices on population dynamics of common voles. Agriculture, Ecosystems \& Environment, 95, 321-325. 
Katzner, T.E., Bragin, E.A., Knick, S.T. \& Smith, A.T. (2003) Coexistence in a multispecies assemblage of eagles in Central Asia. The Condor, 105, 538-551.

Кокко, Н. (2006) Competition for early arrival in migratory birds. Journal of Animal Ecology, 68, 940-950.

Lohmus, A. (2003) Are certain habitats better every year? A review and a case study on birds of prey. Ecography, 26, 545-552.

Marra, P.P. \& Holberton, R.L. (1998) Corticosterone levels as indicators of habitat quality: effects of habitat segregation in a migratory bird during the non-breeding season. Oecologia, 116, 284-292.

Mayfield, H. (1975) Suggestions for calculating nest success. Wilson Bulletin, 87, 456-466.

Millon, A., Bourrioux, J.L., Riols, C. \& Bretagnolle, V. (2002) Comparative breeding biology of hen and Montagu's harriers: an eight-year study in north-eastern France. Ibis, 144, 94-105.

Møller, A.P. \& Hobson, K.A. (2003) Heterogeneity in stable isotope profiles predicts coexistence of populations of barn swallows Hirundo rustica differing in morphology and reproductive performance. Proceedings of the Royal Society of London, $B, 271,1355-1362$.

Morozov, V.V. \& Bragin, E.A. (2005) The pallid harrier in the tundra zone - is it a breeding range shift to the north or an expansion of the breeding area? Russkiy ornitologicheskiy zhurnal, 287, 17-23. [in Russian]

Natural Research (2008a) Pallid Harriers Wintering in India. Http:// www.natural-research.org/news/paha_KZsat.htm [accessed 23 June 2008]

Natural Research (2008b) Satellite Tracking of a Pallid Harrier from Kazakhstan. Http://www.natural-research.org/news/paha_ KZsat.htm [accessed 23 June 2008].

Newton, I. (1979) Population Ecology of Raptors. T. \& A.D. Poyser, Berkhamsted, UK.

Newton, I. (2004) Population limitation in migrants. Ibis, 146, 197-226.
Norris, D.R., Marra, P.P., Kyser, T.K., Sherry, T.W. \& Ratcliffe, L.M. (2004) Tropical winter habitat limits reproductive success on the temperate breeding grounds in a migratory bird. Proceedings of the Royal Society of London, B, 271, 59-64.

PARSONs, J. (1975) Seasonal variation in breeding success of the herring gull: an experimental approach to pre-fledging success. Journal of Animal Ecology, 44, 553-573.

Sanchez-Zapata, J.A., Carrete, M., Gravilov, A., Sklyarenko, S., Ceballos, O., Doñazar, J.A. \& Hiraldo, F. (2003) Land use changes and raptor conservation in steppe habitats of Eastern Kazakhstan. Biological Conservation, 111, 71-77.

Sergio, F., Blas, J., Forero, M.G., Donázar, J.A. \& Hiraldo, F. (2007) Sequential settlement and site dependence in a migratory raptor. Behavioral Ecology, 18, 811-821.

Sergio, S., Pedrini, P. \& Marchesi, L. (2003) Spatio-temporal shifts in gradients of habitat quality for an opportunistic avian predator. Ecography, 26, 243-255.

Snow, P. \& Perrins, S. (1998) The Birds of the Western Palearctic: Vol. 1. Oxford University Press, New York, USA.

\section{Biographical sketches}

Julien TerRaube is studying the ecology and conservation of pallid and Montagu's harriers. BEATRIZ ARROYo's research interests include population ecology of harriers, and conservation and management of agricultural areas. Francois Mougeot has broad interests in behavioural ecology, population dynamics and raptor conservation (red kite, osprey and harriers). Mike Madders has been involved with upland bird species (mainly raptors, and particularly hen harriers) for over 30 years. JEFF WATSON has carried out ecological research on a range or raptor species including merlin and hen harrier in Scotland, Seychelles kestrel, and golden eagle. EVGENY BRAGIN has been working with raptor ecology and conservation in Kazakhstan for over 30 years and is currently a director of the research department of the Naurzum National Reserve. 